\title{
Security Issues of 5th Generation Technology: A Review
}

\author{
Faiza Soomro ${ }^{1}$, Muhammad Ateeq ${ }^{2}$, Cosmas Obiora Ndubuisi ${ }^{3}$, Umar Mohammed Badamasi ${ }^{4}$, Nek \\ Dil Khan ${ }^{5}$ and Muhammad Mohsin Raza ${ }^{6}$ \\ ${ }^{1}$ Central China Normal University, Wuhan China \\ ${ }^{2}$ Xinjiang University, Urumqi China \\ ${ }^{3,4}$ Changchun University of Science and Technology, China \\ ${ }^{5}$ Northeastern University Shenyang, Liaoning Province China \\ ${ }^{6}$ Government College University Faisalabad, Pakistan \\ Ifaizasoormo@gmail.com, ${ }^{2}$ ateeqsajid7@gmail.com
}

\begin{abstract}
In the $20^{\text {th }}$ century, communication placed an important role in our life, whereas $5 \mathrm{G}$ technology is known to be the central area for future networking infrastructure. However, with the high pace of gigantic assaults and protection issues, users and other organizations are not quite sure of the security parameters. In this article, we spotlight the elementary security doubts of 5G Technology. A large portion of the data based on literature and studies released by famous networking giants. Consequently, the paper can illuminate it peruses on what is required from 5G Technology and what are fundamental issues in accomplishing those objects.
\end{abstract}

Keywords: 5G, Telecommunication, Security Issues, IoT.

\section{INTRODUCTION}

The $5 \mathrm{G}$ network is the primary provider of the 2020 communication network that bolsters the Internet of Everything and vast scope heterogeneous links. Currently, a number of standardization organizations have effectively concluded the debate and conceptual testing of $5 \mathrm{G}$ communication technology, with the completion of the 3rd Generation Project (3GPP) R15. The exploratory business arrange has moreover been in the real testing stage, and the versatile web is going to enter the 5th $\mathrm{G}$ time. The $5 \mathrm{G}$ system can empower the consistent coordination of $2^{\text {nd }} \mathrm{G}, 3^{\text {rd }} \mathrm{G}$, $4^{\text {th }} \mathrm{G}$, WiFi, and different access advances, give speeds in the overabundance of $10 \mathrm{~Gb} / \mathrm{s}$, low inactivity, high dependability, super high thickness client limit, the help of high versatility, and so on. Likewise, 5G cannot just offer help for more bountiful application situations in the versatile Internet, for example, super superior quality visual correspondence, media association, portable mechanical computerization, and vehicle interconnection, yet in addition be broadly utilized in the Internet of Things (IoT) including versatile clinical, keen home, modern control, vehicle organizing and environmental observing. Many billions of gadgets are associated with the 5G system to understand the "Web of Everything"[1]. During the most recent couple of years versatile innovation has evolved at a quick pace in multi directional perspectives. On the off chance that cell phones are thought about, these begun as dull gadgets with no such polish. Generally hefty for a cell phone with a small display screen and restricted preparing power. Right now, cell phones are planned with sophisticated shapes and sizes with high resolution screens and preparing power taking after a PC. All these referenced highlights are driven by applications which not just need cell gadgets to perform better and are transfer speed hungry and request higher the information rate on versatile systems. Cell information traffic has been anticipated to rise more than 24-crease from 2010 to 2015 , and an extra at least 500 between the years 2010 and 2020. All these referenced highlights are driven by applications which not just need cell gadgets to perform better and are transfer speed 
hungry and request higher the information rate on versatile systems. Cell information traffic has been anticipated to increase more than 24-crease from
2010 to 2015, and an extra at least 500 between the years 2010 and 2020.

Table 1: The Evolution of $5 G$

\begin{tabular}{|c|c|c|c|c|c|}
\hline & $1 G$ & $2 G$ & 3G & $4 G$ & $5 G$ \\
\hline Era & $1970-1980$ & 1990-2004 & $2004-2010$ & 2010-Now & Soon \\
\hline Technology & $\begin{array}{l}\text { AMP, } \\
\text { TACS }\end{array}$ & $\begin{array}{l}\text { GSM, CDMA, } \\
\text { EDGE, GPRS }\end{array}$ & $\begin{array}{c}\text { UTMS, } \\
\text { CDMA2000, } \\
\text { HSPDA, EVDO }\end{array}$ & $\begin{array}{l}\text { LTE Advanced, } \\
\text { IEEE } 802.16 \\
\text { (WiMaX) }\end{array}$ & $\begin{array}{c}\text { MIMO, mm } \\
\text { Waves }\end{array}$ \\
\hline $\begin{array}{l}\text { Internet } \\
\text { Service }\end{array}$ & N/A & Narrowband & Broadband & $\begin{array}{c}\text { Ultra- } \\
\text { Broadband }\end{array}$ & Wireless WWW \\
\hline Bandwidth & $2 \mathrm{Kbps}$ & $64 \mathrm{Kbps}$ & $2 \mathrm{Mbps}$ & $1 \mathrm{Gbps}$ & More Then $1 \mathrm{Gbps}$ \\
\hline Core Network & PSTN & PSTN & Packet Network & Internet & Internet \\
\hline Frequency & $30 \mathrm{KHz}$ & $1.8 \mathrm{GHz}$ & $1.6-2 \mathrm{GHz}$ & $2-8 \mathrm{GHz}$ & $3-30 \mathrm{GHz}$ \\
\hline Strength & $\begin{array}{l}\text { Voice } \\
\text { Service }\end{array}$ & $\begin{array}{l}\text { SMS, MMS, } \\
\text { SIM Card, } \\
\text { Internet } \\
\text { Access } \\
\end{array}$ & $\begin{array}{l}\text { High Security, } \\
\text { International } \\
\text { Romancing }\end{array}$ & $\begin{array}{c}\text { Speed, High } \\
\text { Speed } \\
\text { Handoffs, } \\
\text { Global mobility } \\
\end{array}$ & $\begin{array}{l}\text { Extremely high } \\
\text { Speed, low } \\
\text { latency }\end{array}$ \\
\hline Weakness & $\begin{array}{l}\text { Significant } \\
\text { security } \\
\text { concerns, } \\
\text { Poor } \\
\text { otherworldly } \\
\text { proficiency, }\end{array}$ & $\begin{array}{c}\text { Slender } \\
\text { information } \\
\text { rates, testing to } \\
\text { uphold } \\
\text { demand for } \\
\text { web/email }\end{array}$ & $\begin{array}{c}\text { The } \\
\text { disappointment of } \\
\text { WAP for web } \\
\text { access, Real } \\
\text { execution } \\
\text { neglected to } \\
\text { coordinate } \\
\text { publicity, Tied to } \\
\text { inheritance }\end{array}$ & $\begin{array}{c}\text { Versatile } \\
\text { express } \\
\text { engineering and } \\
\text { conventions }\end{array}$ & $\begin{array}{l}\text { May exist after } \\
\text { execution. } \\
\text { (Current } \\
\text { difficulties } \\
\text { incorporate } \\
\text { security, } \\
\text { protection, } \\
\text { framework and so } \\
\text { forth) }\end{array}$ \\
\hline
\end{tabular}

As the above table obviously shows the tremendous contrast of information band width rates among various edges is additionally a proof that applications are developing data transmission hungry step by step. Apart from that, bandwidth coverage is another significant filed to focus on, the experience of the consumer and the most important security [2]. Ericsson's flexibility study 2015 predicts that by 2020 Smartphone endorsers will be more than twofold contrasted with what we have at this moment. Versatile information traffic was $55 \%$ more in the primary quarter of 2015 then it was in the principal quarter of 2014 and by (2020) $80 \%$ of the information traffic will be produced by Smartphone [3]. Recently, related researcher has made a few examinations on $5 \mathrm{G}$ organize security [4], [5]. The need for protection requirements and processes for $5 \mathrm{G}$ mobile networks to be addressed in [4].

This overview brings up that the protection and reliability of the client's data and transmission information should be ensured later on 5G organize. Security and protection are among the most concerning area in this day and age of innovation, beneficial thing is that in $4 \mathrm{G}$ innovation decencies are given to security and unwavering quality in correspondence.

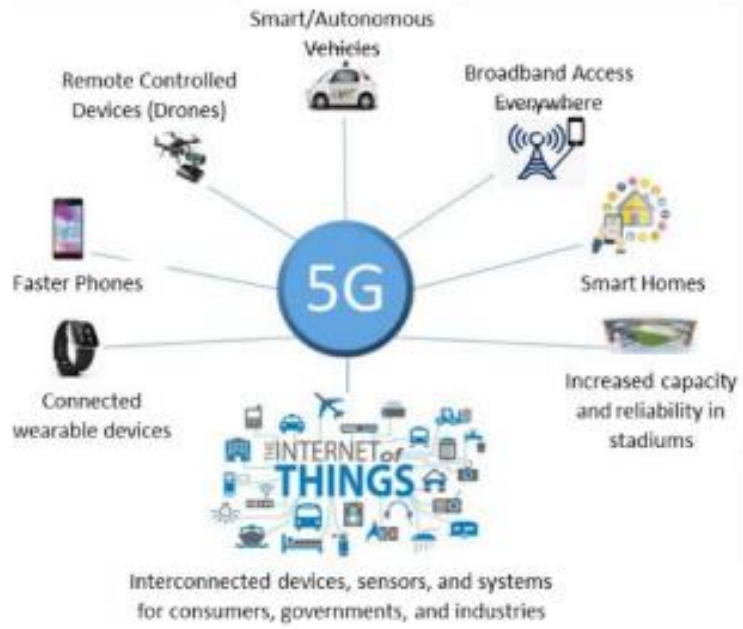

Fig. 1. 5G Communication Technology

The overview [6] sums up the current verification and security insurance plans for $4 \mathrm{G}$ and $5 \mathrm{G}$ organize security and gives a few further proposals for future $5 \mathrm{G}$ security. In this study, the security dangers in the $5 \mathrm{G}$ arrange are predominantly 
separated into four classifications including protection assaults, trustworthiness assaults, accessibility assaults and confirmation assaults. At that point, the accompanying three countermeasures including cryptography, human elements and interruption recognition techniques are talked about for these dangers. The study [7] plans another security engineering for $5 \mathrm{G}$ system and gives a few answers for dangers from WLANs and portable access gadgets in a steady way. In any case, the past reviews [4], [7] essentially center around the $5 \mathrm{G}$ organize security engineering, the security necessities and security weaknesses for explicit situations, which does not have the methodically conversation on $5 \mathrm{G}$ organize security necessities or on the other hand weaknesses, and likely arrangements and open exploration bearings.

\section{IOT (INTERNET OF THINGS)}

As we can see form the exponential advances in portable gadgets, industry experts expect that about 50 billion gadgets around the world will rely on the portable system by 2020[18]. These gadgets will include handheld gadgets which will cover an incredibly large range of gadgets. This exponential development of gadgets linked to the network via flexible arrangement or a variety of method is called IoT (Internet of Things). IoT can add traffic signs, mounted frames, emergency service gadgets, house hold gadgets and much more. As there will be countless devices on the network, we should predict an immense amount of traffic on $5 \mathrm{G}$ network.

\section{CELLULAR NETWORK NEEDS SECURITY}

Cell systems are consistently at a danger of security settles. Regardless of the improvement of cell assemble, there are number of ways by which cell correspondence (both voice and information) can effectively be compromised. [9] The absolute generally normal methods remember interference for the rented lines or basically listening in, utilization of GPS to find client and attack client protection [10]. PDA can be grabbed and can be utilized to imitate character, utilization of sign jammers with man in the center assault, client can accidently download any pernicious programming [11], in light of Internet Protocol locally limited substance can be gotten to by faking the first area of the client, SIM based single direction verification can be traded off.

\section{SECURITY ISSUES IN 5G}

In $5 \mathrm{G}$ security will assume a significant job since it not just backings fundamental parcel transmission traffic yet obliges wide assortment of utilizations. Connecting businesses and essential applications to the web; with $5 \mathrm{G}$, it is foreseen that another model of correspondence offices will rise for the clients and businesses [9].

\section{A. Network Architecture And Infrastructure}

Network architecture and connectivity is a very important part of the use of encryption. In order to help ensure a wide variety of uses with top-of-theline safety standards, $5 \mathrm{G}$ requires a solid devices architecture with the intention of ensuring enhanced safety high lights. For $5 \mathrm{G}$ two basic considerations for compose establishment are being thought of; one is in the direction of virtualization and other follow an ordinary procedure of physical adjustment to the framework entry. Advance Technology, like Network Functions Virtualization (NFV)/Software Defined Network (SDN) and virtualization is seen as a way to make $5 \mathrm{G}$ more effective. Although keeping the endeavors cost low. In standard frameworks, the security of framework parts (NEs) depends upon how well their physical units could be isolated from one another. In any case, in 5G, the separation will work in an extremely various way as virtual NEs are on cloud-based framework. SDN is helpful in redesigning transmission capability and resource utilization, yet then again, it is basic to recall the 5G security structure. In cloud-based designing, security regarding the disengagement of center points could be cultivated by approval of the SDN stream table [12].In the event that conventional framework is taken in to thought, we should remember that normally every system access (BTS/Node B) has an alternate structure. A few reception apparatuses at arrange access are powerful, while some are low controlled; no doubt every receiving wire would be coordinated with its own intensifier. Not to overlook the prerequisites for changed level of Protection, Identified Management and Data Assurance dependent on administrations which are given to the end clients. With the conceivable execution of Internet of things (IoT), there is a high likelihood that attack, for example, DDOS are more incessant to happen. Comparable dynamic attacks can likewise have an impact in upsetting the system with unapproved access or no admittance to system or its assets. So if $5 \mathrm{G}$ suggests physical disengagement of hubs for its administrations, it would be a bad dream in term of adaptability, receiving wire connections also, shared coupling. Cost will be among the issues that 
must be sifted through before choosing physical establish passage adjustments [12][13].

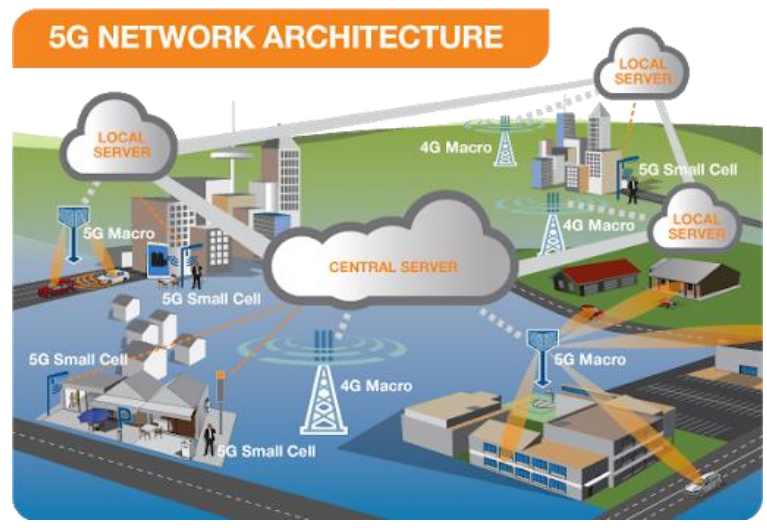

Fig. 3 .Network Architecture and Infrastructure of $5 G$

\section{B. Secure Authentication Method}

In the earth of vertical industry, security necessities for various applications could vary impressively among administrations. In the occasion of Internet of Things (IoT) gadgets, the requirement of lightweight security with fast portable administrations requests high competent security strategy. Default framework based on the standard bounce-by jump protection technique may not be effective enough to form isolated stat-to-end protection for different ty protection for different types of administration. As IoT is gradually being executed and picking up fame, a need of an upgraded and rigid authentication technique is a need for IoT gadgets. So as to forestall unapproved access for instance, biometric based ID could be a truly appropriate verification strategy for advanced mobile phones [12].

\section{Energy efficiency fragments of $5 G$ REMOTE frameworks}

The advancement and development of remote innovation has expanded to a lot in the previous four to five years. Most recent innovation that admits to be capable to satisfy the need according to $5 \mathrm{G}$ prerequisites is Massive multiple-input and multiple-output (MIMO). The general effectiveness of Massive MIMO, innovation over $4 \mathrm{G}$ advances is accomplished by using ideas, for example, a greater number of receiving wires than gadgets, it implies even a portion of the gadgets will go about as a system passageway (gadget to gadget and machine to machine idea). To enable greater information to move limit 30 to $300 \mathrm{GHz}$ with 1 to $10 \mathrm{~mm}$ recurrence will be used with little cells to improve area powerful adequacy [14]. With the referenced methodology Massive MIMO can utilize simple multiplexing and encoding strategies, so that these strategies can be executed utilizing very straightforward equipment. Bringing about low assets use, particularly regarding power [13].

\section{Security Protection}

On account of the wide extent of usages, a need to offer isolated QoS (Quality of Services) is critical. There should be some strategy or limit inside the frameworks which may need to distinguish such an organization being used by the customer, so it could offer better security. Because of ongoing significant security and security issues over cell organize, which incorporate mass reconnaissance and face assemble corridors. The normalization bodies for media transmission, for example, 3GPP and IETF (Internet Engineering Task Force), are being addressed [3]. Here we should not overlook that including upgraded security strategies makes usage of 5G a more noteworthy challenge [12].

\section{E. Drivers}

The drivers for security purposes have continued to bring to the table a trustworthy clear system organization. Telecom executives and wanders will over the long haul need to uncover application programming interfaces (APIs) to the customers and untouchable designers or organization providers to a particular level. For example, to fulfill the explanation behind improved movement using position care, putting away and content variety. Such workplaces for improvements may here and there be maintained by outcast programming parties on shared hardware arranges alongside submitted telecom programming [3].

\section{F. Heterogeneous Access}

As the interest in knowledge and the quantity of gadgets on the web rapidly grows as seen in figure 1 , the requirement for heterogeneous access turns into an indispensable part for 5G arrange [15]. Heterogeneous condition gives concurrent admittance to assorted admittance innovations [16]. Anyway, unique access innovations must endeavor to fabricate an engineering keeping in see $5 \mathrm{G}$ arrange security necessities [12]. Yet, the difficulties related with heterogeneous organize are as yet a worry. Such difficulties incorporate between cell obstruction, dissipated impedance coordination, incapable medium access control, revelation of gadgets and connection arrangement [15]. 


\section{G. Developed Threat Landscape}

The degree or thought for $5 \mathrm{G}$ systems is that it will fill in as a focal foundation for correspondence and various different applications. With this focal engineering approach, a significant concern originates from the clients. On the off chance that the focal design is down because of debacle or some other reason, it will have an effect on a wide variety of communications, what's more, on the daily lives of clients and companies. Along these lines, subsequently 5G needs all around characterized conventions which ought to be versatile against various sort of assaults and catastrophes.

\section{CONCLUSION}

As correspondence innovation develops and advances towards the future, requirement for improved and secure correspondence develops with it. Particularly when we consider $5 \mathrm{G}$ to be a focal space for practically all sort of correspondence including IoT, which will soon to be actualized all through the globe. Albeit a parcel of examination and endeavors are being done to normalize and make a protected system for $5 \mathrm{G}$, yet at the same time there are hazy situations in 5G innovation. So, the need to improve 5G's design and security is of foremost significance. In this paper a portion of the very essential concerns with respect to $5 \mathrm{G}$ security are being featured just as a portion of the improved advances are being brought up. Considering later forswearing of administration assaults bringing about major web blackouts have raised many warnings among research networks, corporate associations what's more, government authorities.

\section{REFERENCES}

[1] T. Nakamura, S. Nagata, A. Benjebbour, Y. Kishiyama, H. Tang, X. Shen, N. Yang, and N. $\mathrm{Li}$, "Trends in Small Cell Enhancements in LTE Advanced," IEEE Communications Magazine, vol. 51, no. 2, pp. 98-105, Feb 2013.

[2] ERICSSON, "Mobility Report," June, 2015 (https://www.ericsson.com/res/docs/2015/erics sonmobility-report-june-2015.pdf).

[3] Schneider, P., \& Horn, G. (Aug. 2015). Towards 5G security. In 2015 IEEE Trustcom/BigDataSE/ISPA, (pp. 1165-1170). IEEE.

[4] Fang, Q., WeiJie, Z., Guojun, W., \& Hui, F. (Sep. 2014). Unified security architecture research for 5G wireless system. In 2014 11th Web Information System and Application Conference (WISA), (pp. 91-94). IEEE.
[5] Vij, S., \& Jain, A. (Mar. 2016). 5G: Evolution of a secure mobile technology. In 2016 3rd International Conference on Computing for Sustainable Global Development, (pp. 21922196). IEEE.

[6] Ferrag, M. A., Maglaras, L., Argyriou, A., Kosmanos, D., \& Janicke, H. (2018). Security for $4 \mathrm{G}$ and $5 \mathrm{G}$ cellular networks: A survey of existing authentication and privacy-preserving schemes. Journal of Network and Computer Applications, 101, 55-82

[7] C. Devices and F. D. Rates, "5G : The Internet for Everyone and Everything."(www.ni.com/pdf/company /en/Trend_Watch_5G.pdf).

[8] Javeed, Danish, et al. "An Efficient Approach of Threat Hunting Using Memory Forensics." International Journal of Computer Networks and Communications Security 8.5 (2020): 37 45.

[9] K. Karthik ,Sobharani kuracha "SECURITY IN WIRELESS CELLULAR," vol. 4, no. 4, pp. 190-197, 2015, IJAIEM.

[10]E. Cheung, J.C.S., Beach, M.A.,\& McGeehan, "Network Planning for Third-Generation Mobile Radio Systems," IEEE Commun. Mag. 32(11), 54.

[11]N. Arcuri, "Technology Solutions for Combating Cellular Fraud," IEEE Commun. Soc. New york Chapter,89th Semin. Proceedings, May 18, 1995.

[12] "5G Security: Forward Thinking Huawei White Paper." (http://www.huawei.com/minisite/5g/img/5G_ Security_Whitepaper_en.pdf)

[13]P. K. Hirani, "Special issues on $5 \mathrm{~g}$ technologies," International Journal of Engineering Technology and Management (IJETM). Volume 2: Issue 2: Page No. 01- 07.

[14]A. Mämmelä, "Energy efficiency in 5G networks," VTT Technical Research Centre of Finland IFIP Networking, Toulouse, France, 20.5.2015 (https://www.irit.fr /networking2015/files/keynote-Mammela.pdf).

[15] Khan, Tahir Ullah. "Internet of Things (IOT) Systems and its Security Challenges." International Journal of Advanced Research in Computer Engineering \& Technology (IJARCET) 8.12 (2019).

[16] W. H. Chin, Z. Fan, and R. Haines, "Emerging technologies and research challenges for $5 \mathrm{G}$ wireless networks," IEEE Wireless Communications 21(2):106- 112 - April 2014.

[17] A. Ghosh, J. Andrews, R. Ratasuk, E. Ratasuk, B. Mondal, P. Xia, N. Mangalvedhe, Han-Shin Jo, T. Thomas, H. Dhillon, T. Novlan, M. Cudak "Heterogeneous Cellular Networks: From Theory to Practice", IEEE 
Communications Magazine Volume: 50, Issue: 6, Page No. 54-64, June 2012.

[18]5G PPP Architecture and Working Group, "View on 5G Architecture", White Paper. Version 1.0, July 2016. (https://5g-ppp.eu/wpcontent/uploads/2014/02/5G-PPP5G-

Architecture-WP-July-2016.pdf).

[19] A. N. Woolf, S. F. Wednesday, and E. D. T. The, "DDoS attack that disrupted internet was largest of its kind in history , experts say," 2016 (https://www.theguardian. com/technology/2016/oct/26/ddos-attack-dynmiraibotnet)

[20] Chris Myers, "What the latest Global DDoS Attack means for Entrepreneurs." (http://www.forbes.com/sites

/chrismyers/2016/10/22/what-the-latest-globalddosattack-means-forentrepreneurs/\#3d1298216483). 